\title{
Effective Strategies in Museum Distance Education
}

\section{Elaine Bontempi The University of Oklahoma, Norman, OK, USA}

ebontempi@ou.edu

\author{
Susan Smith Nash \\ American Association of \\ Petroleum Geologists \\ The University of Oklahoma, \\ Norman, OK, USA
}

smithnash@ou.edu

\begin{abstract}
Museums remain an underutilized resource for educating the public, but this is changing with the development of effective distance learning programs. In recent years, many museums have developed mobile applications, websites, and social networking resources that vary in complexity and purpose. Some have merely provided basic information on hours of operation. Others are quite elaborate, consisting of virtual galleries and supplemental educational programs for teachers interested in incorporating exhibits into classroom or online instruction. For many years, the primary mission of museums was to preserve and display real objects and to help visitors interpret the meaning of these objects. Now there are new options for representing objects and encouraging interaction with them, which results in new possibilities for educating the public. This paper presents the results of an investigation of the distance education approaches used by museums. The results of the study suggested there are at least twelve essential elements in the design of effective distance learning programs for museums. These include contingencies, pre-requisite skills of both learners and developers, target populations, learner characteristics, appropriate topics for distance learning, the nature of the material, instructional design principles, the use of cognitive learning strategies, the incorporation of motivational techniques, interface design, and limitations unique to museums. In general, museums emphasize the importance of visual displays supplemented by audio guides, and they seek to engage the visitor in a way that encourages the visitor to make meaningful connections to his or her life. To develop an effective instructional strategy, the museum education instructional design and technology team focus on instructional design principles, cognitive learning and motivational strategies as well as the best way to effectively deploy new technologies.
\end{abstract}

Keywords: museum education, museum social networks, elearning, mlearning, distance learning, instructional design.

Material published as part of this publication, either on-line or in print, is copyrighted by the Informing Science Institute. Permission to make digital or paper copy of part or all of these works for personal or classroom use is granted without fee provided that the copies are not made or distributed for profit or commercial advantage AND that copies 1) bear this notice in full and 2) give the full citation on the first page. It is permissible to abstract these works so long as credit is given. To copy in all other cases or to republish or to post on a server or to redistribute to lists requires specific permission and payment of a fee. Contact Publisher@InformingScience.org to request redistribution permission.

\section{Introduction}

Historically, distance learning offered by museums was limited to outreach programs, trunks, or traveling exhibits, but recent advances in technology have resulted in focused attempts by museums to keep up with the pace of changes to include mobile applications, webaccessible graphics, videos, and white 
papers, social networking to encourage dynamic interaction, and interactive games and simulations, including virtual worlds. For centuries, the primary mission of museums was to preserve and display real objects and to help visitors interpret the meaning of these objects. Now, interactive multimedia offers new possibilities for exploring and interpreting museum collections. Due to the rush to keep up with the competition, many museums have developed web sites, hosted audio tours downloadable onsite, and have incorporated social networking. The content of these web sites varies greatly, due to the imagination and technological expertise within each museum, as well as funding, and needs of potential audiences. Unfortunately, many museum web sites are still static, uninformative, and contain few, if any, educational services. Many well-endowed museums such as the American Museum of Natural History with their dinosaur app for iPhones and iPads (American Museum of Natural History, 2012) include interactive applications that are usable on mobile devices, and they use the mobile apps to encourage an interactive, personalized experience, not all museums are in a position to develop them.

The museums with poorer budgets must fall back on educational sites, which may be filled with problems including inferior images, faulty links, slow downloading times, outdated resources, poor selection of technical tools, instructional design flaws, inaccurate or incomplete information, and a lack of interactivity. Many of the museum education websites are designed to encourage individuals to visit the museum, resulting rather nebulous learning objectives. Further, many of the resources are designed as narrative pieces to be used as "teacher resources," usually used in conjunction with a physical visit to the museum.

The problem is, how do museums make these web sites effective learning tools? What are the best approaches to offering learning from a distance? Are certain tools more appropriate than others? Are there key elements that combine to make more effective distance learning programs for museums? If so, what are they? To find the answers to these questions, a review was conducted to determine what elements contribute to the evolving theory of effective distance learning.

\section{Literature Review}

Distance learning within museums was examined because museums face unique issues that distance learning programs within many schools do not face. For example, museums deal with real items and, as non-profit organizations, are often faced with funding issues. Museums are considered informal and experiential learning environments since they are generally characterized as offering education based mostly on viewing objects and rather than merely reading text. The study of their artifacts fits into a case-study model of learning since museums allow patrons to pursue their own goals for exploration and discovery. Although museums are typically informal learning environments, they also offer both formal educational opportunities. Formal experiences occur in the form of classes, workshops, day camps, or tours, and usually require a special fee to cover the cost of a professional teacher or leader.

Prior to the development of effective distance learning programs museums were an underutilized educational resource. Until recently, museums were limited in their breadth of outreach, and depended on visitor attendance. The primary mission of museums had been restricted to the preservation and display of real objects. The outreach and partnership programs that existed were formed through local schools, youth groups, churches, and associations. With the development of recent technology, many museums now provide "virtual galleries" over the Internet. With interactive multimedia, new options are now available for the representation of objects and specimens, as well as new possibilities for the exploration, interpretation and knowledge about museum collections. Even so, the majority of museums making use of these new technologies reach out by providing visitors with samples of exhibits and their descriptions, but often fail to offer interactive distance learning programs. Instead, many museum websites are static and often lack detailed or engaging instructional material. 
Museums are increasingly aware of the need to redefine their role in society. Their goal is reaching a broader population, not only to earn more revenue, but to justify any existing subsidy (Caulton, 1998). While many museums offer self-guided tours using a headset or by streaming an mp3 file or other media via an smartphone (iPhone) or other mobile device, they do not often make those same resources available in a way that syncs with the gallery space (Eakle, 2009). Of course there are exceptions, and some of the world's major museums such as the Tate (London), The Hermitage (St. Petersburg, Russia), the Frick (New York City), and Versailles (Paris) have made certain galleries available in a three-dimensional immersive experience via the Google Art Project launched in 2010 (http://www.googleartproject.com/) which allows the visitor to have a semi virtual world experience and create their own collection. However, the educational elements are not structured with a clear instructional strategy. With respect to immersive experience, museum visitors can have an interactive, immersive virtual world experience with museums via Second Life. However, again, the instructional strategies that are employed are not consistent, and they do not take the visitor to the next step to apply their knowledge.

Museums can use their artifacts in conjunction with experiential learning models, as described by Kolb (2001), to provide an authentic, "real world" application of concepts or skills they are learning. While maintaining an emphasis on "doing", learners can gain a deeper understanding of the problems, and can discover and explore relationships. Further, the students should be guided to place the new material within a framework of prior knowledge, and should achieve a higher level of self-awareness in the process.

Motivational models such as those by Keller (1983), Malone (1981), and Maehr (1986) have an important influence on designing effective distance learning programs. In addition to motivational factors, cognitive learning theories lend important concepts to effective instructional design. Comparisons and contrasts between cognitive psychology and behaviorist models as applied to asynchronous online courses are helpful, as provided by Hofstetter (1997). In addition, being mindful of developing an individualized experience is important; for example, the visitor can customize their social networking site (Facebook, Bebo, MySpace, blog) to reflect the experience they had in the museum.

Customizable content as well as a customizable experience appeals to museum visitors because it allows them to sort and classify the content they find most interesting, and to apply it to other situations and in unique contexts to integrate the museum experience into one's real life. For example, many apps are interactive and be used in many different ways. The Museum of Modern Art's iPhone app (MOMA, 2012) allows visitors to download images and information and to incorporate it in their personal space, both in social networks and in their mobile device.

Finally, the form of delivery itself, plays a vital role in the effectiveness of the program because it allows visitors / learners to interact in ways that are comfortable to them. Mobile devices (smartphone and tablets) are perhaps the most quickly-growing delivery system is mobile, with smartphones, handhelds, and tablets. Applications which help bring together museum exhibits, current events, and updates can be quite effective because they're convenient and comfortable for users.

\section{Motivation in Museum Distance Education}

One of the most challenging tasks in designing effective distance learning programs (for museums and other organizations) is keeping learners motivated. Motivation is, in essence, a course pre-requisite for distance learners. In the traditional classroom, there is group pressure within a familiar learning situation, but in the distance learning environment, this motivation to acquire knowledge is often missing. Thus, designers of distance learning programs for museums should build motivational strategies into programs. 
According to Duchastel (1996), motivational factors impact the learning environment and need to be considered in the design of an educational program. Museums may have a bit of an edge over universities or corporation though, because they have direct access to unique stimuli. The situated motivation within museums can be described according to visitors' opportunities to construct personal meaning, make choices, exercise control, engage in collaboration and conversation, adjust task challenges, and derive consequences of performance that promote self efficacy (Gardner, 1997). As such, effective distance learning programs simulate these conditions.

Elements of several motivational models, including: Keller's ARCS (1983),Csikszentmihalyi (1980), Maehr (1986), and Malone (1981), can all be applied toward increasing students' motivational levels as they work with museums' collections and interactive digital resources.

An example of motivating challenges is the immersive, interactive virtual world, Second Life. Many museums have built islands in Second Life (Second Life Wikia, 2011), and visitors are motived by the desire for social interaction, novelty, interaction, and recognition. They can create their own personae (avatars) and engage in productive play with others without the pressure of letting people know who they are.

In Keller's ARCS model (1983), he discussed four factors in the motivation to learn: attention, relevance, confidence, and satisfaction. It may be easy for museums to gain and sustain attention when students come into the building themselves, but it may be a more challenging task to keep their interest through a distance learning program. One of the strategies suggested by Keller and Suzuki (1988) for designing motivating courseware is to avoid dysfunctional attention-getting effects. This can be achieved by controlling student interaction, but doing this can be difficult through web-based instruction or other forms of delivery.

Maehr's model of Personal Investment (1984) examines the effect meaning plays on motivation. Each person attaches a particular meaning to experiences, and it is this personal meaning that determines how much effort the person is willing to invest in certain activities. An example of personal investment applied to museum education occurred in Connecticut where teachers were brought into a teacher education program that included material immediately applicable to their professions:

Connecticut teachers in particular found their participation valuable and meaningful to their teaching practice. Their learning caused them to reconsider the historical roles of Conneetieut residents throughout history and the economic, political, and social impact of the state's maritime history on the country. For instance, Kate, a 2004 participant, noted, "Before I attended the workshop, I tended to teach mostly only from one point of view. Now, I find myself being able to present many different points of views on issues." She went on to describe how the institute challenged her to think beyond the ship captain's viewpoint and to consider the experiences and perspectives of women, slaves, indentured servants, and, what she called, "the lowly crew members." (Grenier, 2010, p. 508)

Finally, Deci and Ryan (1985), suggest that students should have some perceived level of selfdetermination. Self determination refers to the experience of choice. In other words, this is the experience of an internal perceived locus of causality. According to Deci and Ryan (1985), selfdetermination is a human need, and without it, learners will not be intrinsically motivated. Thus, in the application towards distance learning programs, learners should be given some degree of choice and control as to what information will be accessed, and in what order.

An example of employing self-determination theory in a museum education program occurred in museums which allowed students to choose which works to study and to create a diary of their responses (Alverman \& Eakle, 2007). 


\section{Cognitive Theories and Distance Museum Education}

\section{Early Strategies: Information Transmission Model}

In the past, in many distance learning programs, teaching tended to follow the information transmission model. This is where the instructor simply selects the material to be learned, organizes it into a course package, and transmits it to students in a one-way flow of communication to the student (Brown, 1997). Unfortunately, this method promotes passive learning and rote memorization (Brown, 1997). To encourage more effective and meaningful learning, instructional developers in museums (and otherwise) should implement a variety of cognitive learning strategies into the design. According to Laurillard (1993), and Jonassen (1993), to active participation encourages meaningful learning. Through active participation, students arrive at and articulate their own personal understandings, new ideas, and concepts.

\section{Shift to Interactive Strategies:}

According to Piaget, children learn from actions rather than passive observations, and so construct knowledge and understanding for themselves (Caulton, 1998). The most important role of the teacher, according to this theory, is to create environments where learning takes place most effectively, rather than to impart their own knowledge. Teachers should encourage children to ask questions rather than to accept information unquestioningly. Similarly, Piaget's developmental theory of learning has contributed to the spread of hands-on exhibits in museums, with interactive exhibitions providing the foundation that follows Bloom's "taxonomy of learning": cognitive learning, affective learning, and psycho-motor development (Caulton, 1998).

Learners need opportunities to reflect on new material, discuss their understandings and concepts with others, and build conceptual connections to their existing schema. Piaget defines schema as structures or mental units that represent a class of similar actions or thoughts (Ormrod, 1995). Students need to have their preconceptions challenged to bring out inconsistencies and to reveal incompleteness or gaps in their knowledge (Ormrod, 1995). Piaget refers to a couple of related processes termed as assimilation and accommodation. Assimilation involves modifying one's perception of the environment to fit a scheme, and accommodation involves modifying a schema to fit the environment (Ormrod, 1995). Similarly, Anderson (1993) stresses the importance of practice with feedback to advance from declarative to procedural knowledge.

\section{Multiple Intelligences}

Another theory by Gardner $(1983,1991)$, proposes that the brain supports at least seven different abilities or intelligences, and that these develop at different rates and to different extents in individuals. Gardner's view is that these different types of intelligence dominate in different individuals, and the formal school environment doesn't necessarily promote their full development. Caulton (1998), argued that interactive museums are important learning environments because the "rich variety of interpretative techniques can stimulate a multiplicity of intelligences (p.20)."

Thus, to have successful distance learning programs in museums, they must somehow incorporate interactive learning.

\section{Interactive Strategies}

Distance learning programs should also apply other methods of facilitating meaningful learning, because meaningful learning promotes more effective storage and more successful retrieval than rote learning. In addition to tying in new information with existing schema, distance learning programs should attempt to present material in an organized fashion. For example, information can be presented in hierarchical structures, cause-effect relationships, etc., so learners are more likely 
to store it in a similar organizational network (Ormrod, 1995). Ormrod (1995), noted that when students don't see the interconnections among things they learn, they sometimes try to pull those things together in a constructive, yet often inaccurate manner.

\section{Applying knowledge organization strategies through interaction}

To encourage interaction, some museum sites allow their collections to be accessed from metacollections to encourage comparing, contracting, evaluating, and creating schema.

Examples of meta-collections that bring together numerous holdings and encourage interaction with the collections:

- Virtual Library Museums Page: A distributed directory of online museums http://archives.icom.museum/vlmp/

- Mark Harden's Artchives: http://www.artchive.com/

- Olga's Gallery: http://www.abcgallery.com/

- Association of Science and Technology Centers: http://astc.org/sciencecenters/find.php

- Museum Virtual Worlds: http://museumvirtualworlds.org/

Researchers such as Doolittle (2000) explore the role of cognition and constructivism in online learning. To develop a strategy to align learner expectations with museum education goals and to develop the ability to "read" an exhibit, Eakle (2009) developed a series of questions:

\section{Questions for guiding interactive learning}

-Who is represented in the exhibition?

-Who do we not hear from through the exhibition?

-What language does the museum curator use to create a visual image?

-What images, other objects, and spaces does the curator use to craft a language?

-If we were to take away the printed text labels, do our notions of the museum object or exhibition change?

-Whose interests are served by the museum text? Whose interests are not served?

-What view of the world is put forth by ideas in the museum texts? What views are not?

-What are other possible worldviews seen through the museum texts?

(Eakle, 2009, p. 213)

\section{Technology}

Over the last thirty years, museum educators have focused on developing appropriate teaching methods for both face to face teaching (workshops, talks, drama, etc.) and distant learning methods (teacher's packs, loan boxes, and kits). Hooper-Greenhill (1996), noted that current technology enables museums to exist in virtual form over the Internet or on CD-ROM, while virtual reality enables a structure to be reconstructed over its archaeological remains, without damage to the site itself. With the aid of various technological advances, museums now have the opportunity reach out to larger populations. Instead of relying on the public to visit, museums can now come to the public via the Internet.

At its most basic form, distance education takes place when a teacher and student(s) are separated by physical distance, and technology is used to bridge the instructional gap. Different forms of 
delivery provide distance education. In its most primitive form, distance education meant "correspondence study," and mail delivery of print material was the principle format. Technological advances altered the method for distance education, with the most dramatic changes realized via the World Wide Web.

Certain innovative uses of e-learning can support museums' learning objectives, and help visitors better identify the materials in the exhibits, discuss their value, describe how to interpret the works on display, and apply the knowledge to one's own world, and make connections to realworld applications.

\section{Knowledge Object Repositories}

Knowledge objects are digital objects that can communicate across platforms. They tend to be authorware products and can be fairly complex. Mashups and integrated applications are good examples of knowledge objects, and they help individuals use and interact with the museum assets in a way that is both meaningful and useful to the users. Applications for smartphones (iPhone / Android) and tablets are gaining popularity because they allow visitors / users to organize and deliver information.

\section{Learning Object Repositories}

Ways of delivering content constantly evolve, and museums are not always in a position to pay for a complete and total rebuild of all their web-based content or web-based and mobile applications. The key to being able to survive in a fast-paced information technology world is to reuse instructional materials (digital learning objects) and to be able to do it quickly and seamlessly. Many writers have used the analogy of LEGOs to describe the way in which digital learning objects can be used and reused. Basically, the concept is simple - find a way to store and retrieve the objects in a repository so they can be repurposed depending on one's learning goals and overall objectives.

Learning object repositories are often housed in content management systems, which are then accessed for selective deployment via a learning management system.

Museums can then add / revise / update / delete materials as they see fit, and deploy the materials for promotional and social purposes as well as educational.

\section{Streaming Media}

Streaming media has been utilized by online museums since the late 1990s to make recordings of lectures and documentary videos available. As connectivity and access have improved, a social networking approach to using videos has emerged, and many museums encourage individuals to post on Youtube, Flickr, etc. video responses to the exhibits to engage in a kind of ongoing conversation that involves opinions about the exhibits as well as creative and/or expressive responses. For example, museums on university campuses accommodate students in first-year composition, introduction to media, art history, and communications courses who are charged with completing assignments that have to do with permanent or special collections. The museum websites incorporate blogs and/or wikis that allow students to then link to their assignments or embed videos.

\section{Virtual Worlds}

The Google Art Project and virtual worlds such as Second Life encourage immersive experiences with museums. Second Life has been very popular for existing museums as well as artists who 
wish to create a display, and to allow visitors to download materials. Table 1 displays some of the more developed virtual museum sites that are available in Second Life.

\section{Virtual museum sites in second life}

Many museums have created islands in Second Life (Table 1) which allow visitors to participate in gatherings, listen to lectures, and to interact with the collections in a way that allows them to obtain additional information and also to have a more dynamic experience than simply visiting a website. With one's avatar, it is possible to interact with other visitors as well as to experience different types of interactive learning experiences or simulations. For example, in natural science museums, it is possible explore what it might feel like to be inside a subatomic particle accelerator.

Table 1. Islands in Second Life

\begin{tabular}{|l|l|l|}
\hline \multicolumn{1}{|c|}{ Museums } & \multicolumn{1}{|c|}{ Sim } & Coordinates \\
\hline Art Center & Avignon & $(143,179,490)$ \\
\hline The Aho Museum & NMC Campus & $(69,123,26)$ \\
\hline Crescent Moon Museum & Taber & $(198,97,21)$ \\
\hline The Second Louvre Museum & Tompson & $(153,96,100)$ \\
\hline Second Life Science Center & Info Island II & $(114,201,25)$ \\
\hline Museum of Flip Animation & Sphinx & $(202,115,21)$ \\
\hline SL Computer History Museum & Info Island II & $(225,51,23)$ \\
\hline SL Historical Museum & Phobos & $(216,166,32)$ \\
\hline Bayside Beach Galleria - Museum & Flyingroc Chung & $(72,124,35)$ \\
\hline International Spaceflight Museum & Spaceport Alpha & $(48,75,22)$ \\
\hline Fort Malaya Malay History Museum & Ocean Pines & $(135,155,22)$ \\
\hline Star Trek Museum of Science & Ocean Pines & $(37,215,25)$ \\
\hline Tarot Card Museum & Hantu & $(204,100,29)$ \\
\hline Virtual Starry Night - Vincent van Gogh Second Life & Luctesa & $(110,200,66)$ \\
\hline The Avnet Technology Museum & Avnet & $(150,154,39)$ \\
\hline The Neufreistadt Museum of Contemporary Art & Neufreistadt & $(181,136,183)$ \\
\hline
\end{tabular}

http://secondlife.wikia.com/wiki/List_of museums and galleries in Second Life 
While many of the sites in Second Life involve interaction, most link to downloadable materials or out to other websites. Unfortunately, most of the material that is available for download in museums consists of narratives:

"the most common tools used in education are at the less interactive "narrative" level and that research about social network tools show potential for enabling high levels of interactivity in educating online. Researchers have emphasized the need for interactivity in online teaching, but question if it is actually happening" (Saiki, 2010, 52).

Museums with Second Life islands face a number of hurdles in the sense that it is often difficult to attract a large number of visitors due to the continuing awkwardness of the interface and the steep learning curve required to navigate comfortably with one's avatar. Further, the cost of building, expanding, and maintaining an island can be prohibitive. For that reason, many museums are turning to mobile applications in order to encourage a more immersive and interactive experience than simply observing an object and reading a narrative.

\section{Online Collaborations}

Incorporating social networks can help develop collaborations and interactivity, but many museums do not feature much more than areas to comment in their blog. It is possible to share materials through Facebook and "like" exhibits. Using social networking can be effective with marketing efforts and to share impressions, but often there are no clearly stated learning outcomes, and the educational elements are not organized to be as powerful as they could be if they asked visitors to apply their knowledge in the form of assessments (quizzes, writings, creating e-portfolios).

\section{E-Portfolios}

Museums' digital content can be incorporated in individual and collaborative projects, for creative, educational, and social networking uses. E-portfolios may be built in social networking sites (Facebook, etc.), as well as in personal blog spaces.

\section{Wikis, Blogs, Social Collaboration}

Collaborative knowledge-building and knowledge-sharing tools are commonly used by museums to encourage individuals to familiarize themselves with the collection and the contexts surrounding them. While wikis and blogs have been popular forms, they are by no means the only ones, and new applications emerge regularly.

\section{Cost-Savings Using E-Delivery}

There are many advantages of using mobile applications for delivering museum content. Perhaps the most obvious one is cost, provided that the project is planned well and digital objects are reused and repurposed to keep up with the quickly changing platforms, devices, and delivery modes. Further, it is possible to piggyback on the technologies that learners already feel comfortable with, such as blogging, social networking, texting, and the use of smartphones and tablets, to encourage use of digital assets, customization, incorporation to one's life, and connection to prior knowledge and experience.

The advantages of e-delivery have been recognized for decades. According to Roberts (1994), there are three major areas that combine to produce low costs of the Internet: Internet architecture, Internet Services, and the economic structure of the Internet. Another advantage of the Internet is that it allows the publication of a wide variety of learning resources. In addition, with topics presented in hypertext, the learner has a degree of control over the type and amount of information accessed. Furthermore, learners become more active participants in the construction of 
knowledge building when making connections between new and old concepts Hypertext is highly suited for facilitating this process.

With the development of distance learning programs, museums are more available educational resources. It is hoped this study will contribute toward understanding what elements are vital in designing distance learning programs for museums. If museums can take advantage of advancing technologies and effective design principles, they may be able to reach out to the community more than ever thought possible. In addition, if museums can effectively educate from a distance, then perhaps they won't have to depend on in-person visitation by the public.

\section{Conclusions}

Museums face unique issues because they handle real items and artifacts, and, since most are non-profit organizations, they are constantly challenged by budget constraints. Research suggests three main elements of design to incorporate in distance learning programs: motivational strategies, cognitive learning theories, and appropriate selection of mediums or methods of delivery. Motivational techniques are recommended to increase interest and perseverance, cognitive theories help learners process and retain information better, and certain technologies are preferred over others, with attention to subject matter and target audience. Finally, when museums use the technology that is widely used by visitors (smartphones, tablets, etc.), there is a higher likelihood

of situated learning, which often results in highly motivated learners and learning.

\section{References}

Alvermann, D. E., \& Eakle, A. J. (2007). Dissolving learning boundaries: The doing, re-doing, and undoing of school. In D. Thiessen \& A. Cook-Sather (Eds.), International handbook of student experience in elementary and secondary school (pp. 143-166). Dordrecht, The Netherlands: Springer.

American Museum of Natural History. (2012). Dinosaur App. Retrieved from http://www.amnh.org/apps/dino.php

Anderson, J. R. (1993). Rules of the mind. New Jersey: Lawrence Erlbaum Associates.

Brown, A. (1997). Designing for learning: What are the essential features of an effective online course? Australian Journal of Educational Technology, 13(2), 115-126.

Caulton, T. (1998). Hands-on exhibitions. New York: Routledge.

Caro, M. A. (2006). You are here: The NMAI as site of identification. American Indian Quarterly, 30(3), $543-557$.

Chall, J. S. (2000). The academic achievement challenge: What really works in the classroom? New York: Guilford.

Ching-Yuan Huang, \& Lichun Chiang. (2007). Ethics \& Behavior, 17(4), 367-386.

Cornford, I. R. (1997). Ensuring effective learning from modular courses: a cognitive psychology-skill learning perspective. Journal of Vocational Education and Training, 49(2). 237-251.

Creswell, J. W. (1998). Qualitative inquiry and research design: Choosing among five traditions. Thousand Oaks, CA: Sage Publications.

Czajkowski, J. W. (2011). Changing the rules: Making space for interactive learning in the galleries of the Detroit Institute of Arts. Journal of Museum Education, 36(2), 171-178.

Csikszentmihalyi, M. (1990). Flow: The psychology of optimal experience. New York: Harper Perennial.

Deci, E. L., \& Ryan, R. M. (1985). Intrinsic motivation and self-determination in human behavior. New York: Plenum Press. 
Do, J., \& Lee, I. (1999). World wide web in the virtual classroom. Available at http://computed.coe.wayne.edu/Vol3/do.html <http://www.nova.edu/ duchaste

Do, J., \& Lee, I. (1997). World Wide Web in the virtual classroom. Compute-Ed, 3, Retrieved June 2, 2007, from http://pandora.nla.gov.au/nphwb/19981202130000/http://www.education.uts.edu.au/projects/comped/Vol3/do.html

Doolittle, P. (2000). Constructivism and online education. 1999 Online Conference in Teaching Online in Higher Education. Retrieved from http://edpsychserver.ed.vt.edu/workshops/tohe1999/pedagogy.html

Duchastel, P. (1996). A motivational framework for web-based instruction. Available at http://www.nova.edu/ duchaste

Eakle, A. J. (2009) Museum literacies and adolescents using multiple forms of texts "on their own." Journal of Adolescent \& Adult Literacy. 53(3), 206.

Gardner, H. (1983). The frames of the mind: The theory of multiple intelligence. New York: Basic Books.

Gardner, H. (1991). The unschooled mind: How children think and how schools should teach. New York: Basic Books.

Grenier, R. S. (2010). Now this is what I call learning! A case study of museum-initiated professional development for teachers. American Association for Adult and Continuing Education. 60(5) 499-516.

Hein, G. E. (1998). Learning in the museum. New York: Routledge.

Hofstetter, F. (2001). Internet Literacy (2nd ed,.). New York: McGraw-Hill.

Hofstetter, F. (2001). Multimedia literacy (3rd ed.). Textbook and CD-ROM combination. New York: McGraw-Hill Publishing Company.

Hooper-Greenhill, E. (1994). Education, communication and interpretation: Towards a critical pedagogy in museums. In Hooper-Greenhill (Ed.), The educational role of the museum (pp. 3-27). New York: Routledge.

Kanaoka, M. (1999). A technical writing course aimed at nurturing critical thinking skills. Language Teacher Online. Retrieved from http://langue.hyper.chubu.ac.jp/jalt/pub/ttl/99/sep/kanaoka.html

Keller, J. (1983). Motivational design of instruction. In C. Reigeluth (Ed.), Instructional design theories and models: An overview of their current status. Hillsdale, NJ: Erlbaum.

Keller, J. (1987). Development and use of the ARCS model of instructional design. Journal of Instructional Development, 10(3), 2-10.

Kolb, A., \& Kolb D. A. (2001). Experiential learning theory bibliography 1971-2001. Boston, MA: McBer and Co. Retrieved from http://trgmcber.haygroup.com/Products/learning/bibliography.htm

Kolb, D. A. (1976). The learning style inventory: Technical manual. Boston, MA: McBer.

Kolb, D. A. (1981). Learning styles and disciplinary differences. In A. W. Chickering (Ed.), The modern American college. San Francisco: Jossey-Bass.

Kolb, D. A. (with J. Osland and I. Rubin). (1995a). Organizational behavior: An experiential approach to human behavior in organizations 6e. Englewood Cliffs, NJ: Prentice Hall.

Kolb, D. A. (with J. Osland and I. Rubin). (1995b). The organizational behavior reader 6e. Englewood Cliffs, NJ: Prentice Hall.

Kolb. D. A., \& Fry, R. (1975). Toward an applied theory of experiential learning. In C. Cooper (Ed.), Theories of group process. London: John Wiley.

Lewis, C., \& Fabos, B. (2005). Instant messaging, literacies, and social identities. Reading Research Quarterly, 40(4), 470-501. doi:10.1598/RRQ.40.4.5

Maehr, M. L. (1984). Meaning and motivation: Toward a theory of personal investment. In R. Ames \& C.Ames (Eds.), Research on motivation in education, Vol 1: Student motivation (pp. 115-144). 
Malone, T. (1981). Toward a theory of intrinsically motivating instruction. Cognitive Science, 4, 333-369.

McDade, S. (1995). Case study pedagogy to advance critical thinking. Teaching of Psychology, 22(1), 1112.

MOMA, Museum of Modern Art. (2012). MOMA iPhone App. Retrieved from http://www.moma.org/explore/mobile/iphoneapp

Nicholson, A., \& Ngai, J. Y. K. (1996). Managing the development and production of interactive multimedia courseware in education. Australian Journal of Educational Technology, 12(1), 35-45.

Ormrod, J. E. (1995). Human learning (2nd ed.). New Jersey, Prentice Hall.

Roberts, M. (1994). Why is the internet so cheap? Educom Review. 29(6), 1-2.

Rossi, M. (2010). Fabricating authenticity: Modeling a whale at the American Museum of Natural History, 1906-1974. ISIS, 101(2), 338-361.

Saiki, D., \& Robbins, A. (2008). Featuring clothing and textile collections online. ASLIB Proceedings: New Information Perspective, 60(2), 99-110.

Saiki, D. (2010). Interaction online: A content analysis of museum education websites. Journal of Learning Design, 2010, 50-62.

Second Life Wikia. (2011). List of galleries and museums in second life. Retrieved from http://secondlife.wikia.com/wiki/List_of_museums_and_galleries_in_Second_Life

Sterman, N., \& Brockenbrough, A. (1990). The mediated museum: Computer based technology and museum infrastructure. Journal of Educational Technology Systems, 19(1), 21-31.

Strauss, A., \& Corbin, J. (1998). Basics of qualitative research: Techniques and procedures for developing grounded theory (2nd ed.). Thousand Oaks, CA: Sage Publications, Inc.

Weinstein, C. F., \& Mayer, R. F. (1986). The teaching of learning strategies. In M.C. Wittrock (Ed.), Handbook of research on teaching (3rd ed). New York: Macmillan.

Weinstein, C. F., \& Meyer, D. K. (1994). Learning strategies, teaching and testing. In T. Husen \& T. N. Postlethwaite (Eds), The international encyclopedia of education (2nd ed). Oxford: Pergamon Press.

Zvacek, S. M. (1991). Effective affective design for distance education. Tech Trends, 36(1), 40-43.

\section{Biographies}

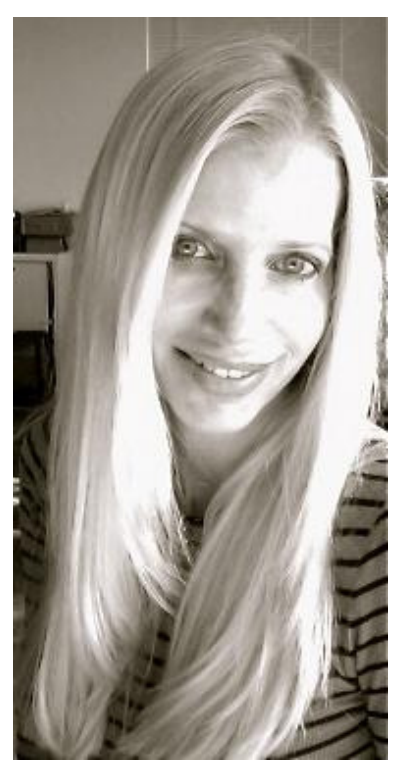

Elaine Bontempi was raised in both Oklahoma and Northeastern Vermont, and after graduating from high school, moved to Tucson, Arizona, where she studied Art at the University of Arizona before changing majors to Psychology. While in Tucson she worked for the Tucson Museum of Art and led an art therapy program for "At Risk" and abused children and adolescents in the community with Las Familias. After living in Tucson for almost seven years she returned to Oklahoma and earned her Master's and $\mathrm{PhD}$ from the University of Oklahoma in Educational Psychology \& Technology with a dual emphasis in Instructional Design. Her dissertation research was conducted in Southeast Alaska and throughout the state of Oklahoma, and focused on the "School Experiences of American Indian and Alaska Students: A Closer Look at Self Determination Theory." For the past 12 years, Elaine has worked as an Instructional Design consultant, developing, implementing and evaluating educational and training programs for various institutions including the Federal Aviation Administration, National Weather Service, Oklahoma's Dept of Education, All Kinds of Minds, Pearson Publishing Co., McGraw Hill Publishers, Thomson 
Press, Fred Jones Jr. Museum of Art, Sam Noble Oklahoma Museum of Natural History, the University of Oklahoma, Excelsior College, and Corinthian/Everest Colleges. In addition, she has been creating, executing and evaluating face to face, online, and hybrid courses for the University of Oklahoma, Excelsior College and Corinthian Colleges for several years as well. Currently, she is working towards her LPC (licensed practicing counselor) and ATR (art therapy), with a focus on multicultural counseling, PTSD and counseling women.

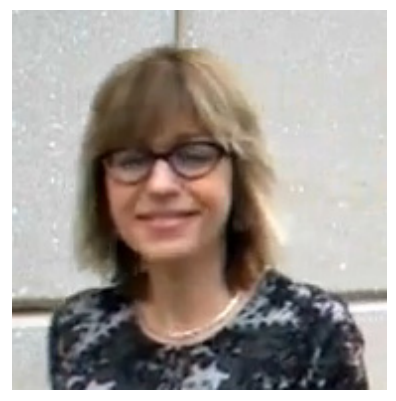

Susan Smith Nash began her professional career as a petroleum geologist and has continued to be involved in oil and gas exploration and development while diversifying into other areas including economics, composition, and e-learning. Nash has held positions that bring together disciplines, including Director of Engineering and Geosciences Continuing Education at the University of Oklahoma, Associate Dean of Graduate Studies at Excelsior College, and Director of Education and Professional Development at the University of Oklahoma. Recently, she organized a series of conferences, workshops, and webinars that incorporated case studies and processes / procedures used in petroleum exploration. Her educational background includes a B.S. in Geology, M.A. in English, and Ph.D. in English from the University of Oklahoma, and continuing graduate studies in economics and instructional design. Her edu-blog, E-Learning Queen (elearningqueen.com) has received awards and recognition. 